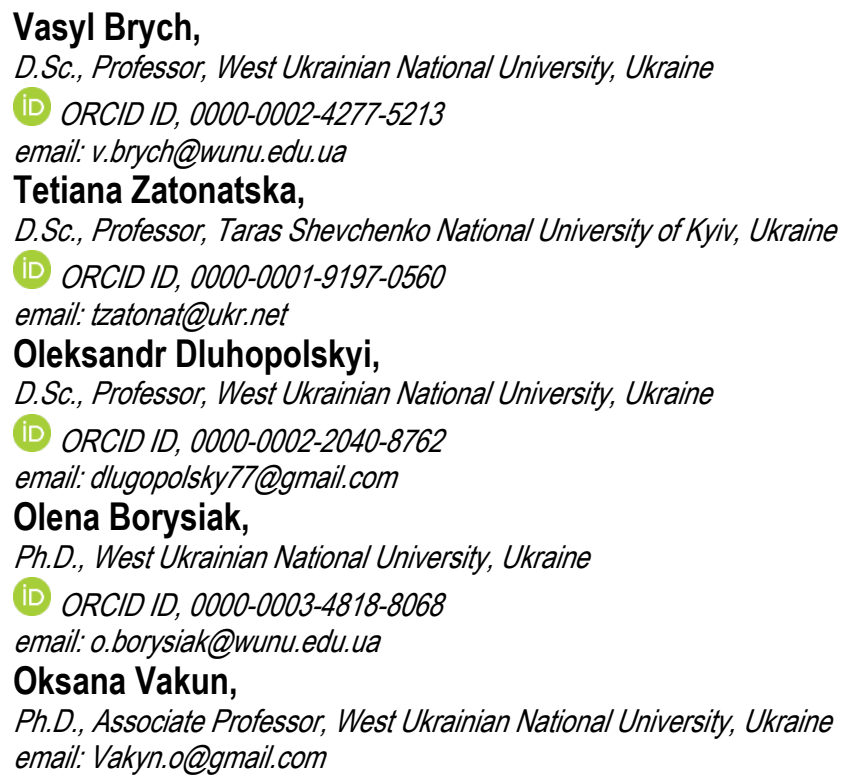

Correspondence author: tzatonat@ukr.net

\title{
ESTIMATING THE EFFICIENCY OF THE GREEN ENERGY SERVICES' MARKETING MANAGEMENT BASED ON SEGMENTATION
}

Abstract. Energy security undergoes risks at the level of production, storage, distribution, supply and consumption of energy. Seasonal decrease or increase in demand for energy resources at the consumers' level due to climate change has a negative impact on the energy system balancing. The article is devoted to estimating the factors of the green energy services' marketing management and developing a model for estimating of green energy as an innovative product based on the segmentation of the energy market. The energy market segmentation allows to single out its basic components based on the use and consumption of energy from natural non-renewable sources, and the production and consumption of alternative energy (green energy), as well as energy services of different levels. To determine the factors of the green energy services marketing management, the energy market was segmented. The innovative development of green energy as a product, green energy services and smart energy grid based on the use of energy from natural renewable sources was discovered. There is a positive trend of increasing demand for electric vehicles and expanding the geography of charging stations. For further positioning of green energy as an innovative product in the energy market, it is advisable to conduct educational campaigns to promote electric vehicles, study the environmental behavior of transport users et. The active process of the Ukrainian energy market reforming is based on competition and considers the international experience of reform. In particular, the electricity market, the gas market, which ensure the operation of energy distribution systems, the diversification of energy supply sources, and the possibility of independent choice of consumers of gas or electricity suppliers are already functioning. This led to the use of an integrated segment approach to modeling the estimating of green energy as an innovative product in the energy market. To determine the green energy estimating as an innovative product in the energy market,

Cite as: Brych, V., Zatonatska, T., Dluhopolskyi, O., Borysiak, O., Vakun, O. (2021). Estimating the Efficiency of the Green Energy Services' Marketing Management Based on Segmentation. Marketing and Management of Innovations, 3, 188-198. http://doi.org/10.21272/mmi.2021.3-16 
V., Brych, T., Zatonatska, O., Dluhopolskyi, O., Borysiak, O., Vakun. Estimating the Efficiency of the Green Energy Services' Marketing Management Based on Segmentation

used of the interval models described by the discrete difference equations. Taking into account the above, a promising area for further research is to develop a methodological approach to assessing the management model for the promotion of green energy services in the context of the development of smart grids.

Keywords: market segments, sustainable development, climate change, alternative energy, climate policy, renewable energy sources, energy and environmental safety, energy management, Smart Grids, energy service companies.organizational scheme, energy, smart grids, stakeholders, maturity model.

Introduction. The effects of climate change led to the search for innovative approaches to the economic use of natural resources by strengthening transnational cooperation. Improving the efficiency of the transnational energy market, ensuring energy efficiency and energy saving of enterprises and households anticipate the transition to the production, marketing and consumption of "green energy", as well as the development of "smart energy" networks. Climate challenges in recent decades are forcing a change in attitudes towards forms of interaction with the environment. The reduction of natural energy resources determines the search for alternative energy sources. In the coming decades, the industry will have to solve a double task - to dramatically reduce the carbon footprint and at the same time increase the reliability and sustainability of energy supply. Measures to adapt to climate change in the energy sector include assessing the impact of climate change on the industry, modeling future energy demand and potential peak periods.

Literature review. Economic losses from more frequent climate-related extreme events are increasing. In the EU, these losses already average over EUR 12 billion per year. Conservative, lower bound estimates show that exposing today's EU economy to global warming of $3^{\circ} \mathrm{C}$ above pre-industrial levels would result in an annual loss of at least EUR 170 billion (The new EU Strategy on Adaptation to Climate Change, 2021). As a result, current European activities include the development of measures to adapt to climate change by 2030 and 2050 and dissemination through the formation of an extensive regulatory framework (e.g., European Green Deal (2019), Climate Target Plan to 2030 (2020), Forging a climate-resilient Europe (2021)). Their provisions are implemented through the development of political and legal instruments of national climate policy (Nationally defined contributions, Long-term low-carbon development strategies, National plans for energy and climate, National strategies for adaptation to climate change) (Mazzai, 2021). The Cabinet of Ministers of Ukraine has developed a draft Strategy for Energy Security and Adaptation to Climate Change until 2030.

The European Green Deal (The European Green Deal, 2021), adopted by the European Commission in December 2019, approved a course towards climate neutral development of the economy and society until 2050 and became another reboot of the energy policy of states aimed at preserving the environment and preventing climate change. The EU committed to climate neutrality by 2050 and a more ambitious emissions reduction target of at least $55 \%$ by 2030 , compared to 1990) (The new EU Strategy on Adaptation to Climate Change, 2021). In this context, the dissemination of European experience in climate change adaptation and the formation of knowledge and skills in the use of digital energy efficiency management technologies at the national and regional levels plays an important role.

There is important to develop the energy services (Urge-Vorsatz et al., 2007; Shengin et al., 2019; Liakhovych et al., 2021) based on smart grid technologies in the energy market and formation a municipal environmental policy and environmental sustainability of the electric vehicle (Van Der Kam et al., 2019; Dontu et al., 2019), introduction an energy management system in households and enterprises with a combination of solar heat and bioenergy, replace fossil fuels with bioenergy in district heating (Maaki et al., 2021; Lindroos et al., 2021) as an environment for the implementation of such an innovative product in the energy market as green energy (biofuels). Instead, the world community is currently not wellprepared for the increasing intensity, frequency and prevalence of climate change, particularly with the growing emissions. Resilience to climate change needs to be built quickly - from public awareness and 
concern to mass adaptation action. To implement these tasks, the green energy services marketing management should improve.

Methodology and research methods. The purpose of the research is to estimate the factors of the green energy services marketing management and developing a model for estimating of green energy as an innovative product based on the segmentation of the energy market.

The efficiency of energy market segmentation depends on the clarity and sequence of the stages of its implementation. In general, the segmentation algorithm should include the following stages: formulation of segmentation goals, selection of features and segmentation methods, dividing the market into segments, selection of segmentation criteria, assessment of segments, selection of target segments, development of a positioning strategy (Slokva, 2017).

In the scientific literature (Slokva, 2017), the following segmentation methods are distinguished:

1) a priori is used when the segmentation signs, the number of segments, their characteristics, the map of interests are known in advance. This method is often used in cases where segmentation is not a part of the current research, but it serves as an auxiliary tool in solving other marketing problems. Sometimes this method is used with a small number of market segments;

2) correlation segmentation (post hoc) is used in case of ambiguity of the segmentation signs and the essence of the segments themselves, for the identification of which a survey is carried out. Depending on the expressed attitude towards a certain group of variables, the respondents are assigned to the corresponding segment. This method is used in the segmentation of consumer markets, the segment structure of which is not determined by the service provided;

3) segmentation matrix. Each of the resulting segments should be considered for possible profitability and choice as a target market. The segment's profitability is determined by the same structural forces and the attractiveness of the industry as a whole. In particular, in order to determine the market segments that have the highest degree of attractiveness, it is necessary to assess the segment's accessibility, its potential and development opportunities;

4) the method of grouping according to one or several characteristics and the method essence consists in the sequential breakdown of a set of objects into groups according to the most significant characteristics;

5) methods of multivariate statistical analysis or methods of multivariate classification as they are also known; the classification is carried out according to the complex of analyzed features simultaneously. This group of methods includes methods of automatic classification or cluster analysis, taxonomy, factor analysis.

To determine the green energy estimating as an innovative product in the energy market, we use the interval models based on difference operators, which describe indicators of economic processes by intervals of possible values or functional corridors. These are mathematical models, which describe the influence of energy market segmentation factors on the dynamics of green energy production indicators.

As an indicator of the green energy estimating as an innovative product in the energy market, we will choose the indicator of the energy consumption from renewable energy sources. There is a statistical error in the formation of statistical reports. Accordingly, in the work will be used the indicator of the green energy estimating in the energy market based on interval models of the following form:

$$
[P r]=\left[\operatorname{Pr}_{i}^{-} ; \operatorname{Pr}_{i}^{+}\right], i=1, \ldots, N \text {, }
$$

where $P r_{i}^{-}=P r_{i}-\delta, P r_{i}^{+}=P r_{i}+\delta$, is an error, which is limited by a known range of allowable values; $N$ - the number of time series in the statistics.

To describe the dynamic interval models of the indicator of the green energy estimating in the energy market, we take the following discrete difference equations:

1) the linear: 


$$
[\operatorname{Pr}]_{n+1}=\alpha \cdot[\operatorname{Pr}]_{n}+\sum_{i=1}^{k} \beta_{i} \cdot C_{i n+1},
$$

2) the nonlinear:

$$
[\operatorname{Pr}]_{n+1}=\alpha \cdot[\operatorname{Pr}]_{n}+\sum_{i=1}^{m} \beta_{i} \cdot \varphi_{i}\left(C_{i n+1}\right),
$$

where $n$ is a time discretion, $n=0, \ldots, N-1, N$ - the number of time series in the statistics; $P r_{n+1}$ - the value of the indicator of the green energy estimating in the energy market in the $(n+1)$-th discrete time; $P r_{n}$ - the value of the indicator of the green energy estimating in the energy market in the $n$-th time; $\vec{C}_{n}=\left(C_{1, n}, \ldots, C_{k, n}\right)^{T}$ - the vector of factors of the green energy estimating in the energy market in the $n$-th discrete time $i=1, \ldots, k ; k$ is the number of factors; $\varphi_{i}\left(C_{i n+1}\right), i=1, \ldots, m$ - basic functions in the form of a polynomial, which define the nonlinear character of the model; $\alpha, \beta_{i}, i=1, \ldots, k-$ coefficients of the model.

To evaluate the coefficients of the model, we used methods of analysis of interval data which are based on two-sided optimization with the using of linear programming problems. As a result, we received interval forecast corridors of the studied indicators of the following form:

$$
[P \hat{r}]_{n+1}=\hat{\alpha} \cdot[P \hat{r}]_{n}+\sum_{i=1}^{m} \hat{\beta}_{i} \cdot \varphi_{i}\left(C_{i n+1}\right),
$$

where $[\hat{P} r]_{n},[\hat{P} r]_{n+1}$ - forecast intervals of the green energy positioning in the energy market; $\hat{\alpha}, \hat{\beta}_{i}$ - rating of model coefficients and positioning factors.

To establish the factors of green energy estimating in the energy market, it is possible to took the energy market factors' segments: competitor, energy source, territorial, product, human potential. To determine the model based on interval data, we used a system of interval linear equations of the following form:

$$
\left\{\begin{array}{l}
{\left[\mathrm{Pr}_{1}\right]=a \cdot \mathrm{Pr}_{0}+b_{1} \cdot \varphi\left(C_{1,1}\right)+\ldots+b_{m} \cdot \varphi\left(C_{1, k}\right),} \\
{\left[\mathrm{Pr}_{2}\right]=a \cdot \mathrm{Pr}_{1}+b_{1} \cdot \varphi\left(C_{2,1}\right)+\ldots+b_{m} \cdot \varphi\left(C_{2, k}\right),} \\
{\left[\mathrm{Pr}_{3}\right]=a \cdot \mathrm{Pr}_{2}+b_{1} \cdot \varphi\left(C_{3,1}\right)+\ldots+b_{m} \cdot \varphi\left(C_{3, k}\right),} \\
{\left[\mathrm{Pr}_{4}\right]=a \cdot \mathrm{Pr}_{3}+b_{1} \cdot \varphi\left(C_{4,1}\right)+\ldots+b_{m} \cdot \varphi\left(C_{4, k}\right) .}
\end{array}\right.
$$

Instead of the interval value $P r_{n}, n=0, \ldots, 3$, we used the value of the center of the interval. Such systems of equations are based on two-way optimization with the use of linear programming methods of the following conditions:

$$
\begin{array}{r}
\left\{\begin{array}{r}
\operatorname{Pr}_{1}^{-} \leq a \cdot P r_{0}+b_{1} \cdot \varphi\left(C_{1,1}\right)+\ldots+b_{m} \cdot \varphi\left(C_{1, k}\right) \leq P r_{1}^{+}, \\
\operatorname{Pr}_{2}^{-} \leq a \cdot P r_{1}+b_{1} \cdot \varphi\left(C_{2,1}\right)+\ldots+b_{m} \cdot \varphi\left(C_{2, k}\right) \leq P r_{1}^{+}, \\
\operatorname{Pr}_{3}^{-} \leq a \cdot P r_{2}+b_{1} \cdot \varphi\left(C_{3,1}\right)+\ldots+b_{m} \cdot \varphi\left(C_{3, k}\right) \leq P r_{1}^{+}, \\
\operatorname{Pr}_{4}^{-} \leq a \cdot \operatorname{Pr}_{3}+b_{1} \cdot \varphi\left(C_{4,1}\right)+\ldots+b_{m} \cdot \varphi\left(C_{4, k}\right) \leq P r_{1}^{+}
\end{array}\right. \\
{\left[\operatorname{Pr}_{i}\right]=\left[\operatorname{Pr}_{i}^{-} ; P r_{i}^{+}\right], i=0, \ldots, 4,}
\end{array}
$$


where $P r_{i}^{-}=P r_{i}-\delta, P r_{i}^{+}=P r_{i}+\delta$ - lower and upper limit of the range of permissible values of the green energy estimating in the energy market, including the value of statistical error.

The proposed conceptual model for estimating green energy as an innovative product in the energy market made it possible to determine the priority directions for the development of energy market segments based on the development of a chain of partnerships between energy enterprises, producers and suppliers of alternative energy sources, an energy service company (development of a company's behavior strategy in the energy market: diversification, differentiation, concentration, etc.), local governments, consumers of green energy.

Results. In the scientific community (Zaverbnyi, 2013) among the factors of lowering prices for energy resources in the energy market of Ukraine are the following ones: an increased competition between mining (generating) and supply companies; elimination of intermediary links (such as State Enterprise "Energorynok", NJSC Naftogaz of Ukraine, etc.) when purchasing electricity, natural gas, by qualified consumers; increasing the qualification level of consumers and the ability to choose suppliers of all types of energy resources (demonopolization of energy markets), the abolition of hidden (sometimes explicit) cross-subsidization of certain groups of consumers, and the like.

According to the forecast data (Energy of Ukraine, 2020) in 2040, half of the world's energy will be consumed in the form of electricity, while the increase in production and consumption will be carried out due to renewable energy sources (Table 1). Let us consider the dynamics of production and consumption of electricity in Ukraine. According to the data (Information note, 2019), since 2019, the volume of electricity production by power plants belonging to the United Energy Ukraine reached 153,964.8 million $\mathrm{kWh}$, which is $5,385.8$ million $\mathrm{kWh}$ or $3.4 \%$ less compared to 2018 . However, in 2019 , the production of electricity by renewable energy sources (wind power plant, solar power plant, biomass) increased by 2,909.6 million $\mathrm{kWh}$ or $110.5 \%$ compared to 2018 and amounted to $5,542.3$ million $\mathrm{kWh}$.

Table 1. Forecast of energy consumption structure in the world by fuel type, $\%$

\begin{tabular}{lccc}
\hline \multicolumn{1}{c}{ Type of energy } & $\mathbf{2 0 1 7}$ & $\mathbf{2 0 4 0}$ & Deviation between 2040 and 2017 \\
\hline Renewable energy sources & 4 & 15 & +11 \\
Gas & 23 & 26 & +3 \\
Hydropower & 7 & 7 & 0 \\
Atomic energy & 4 & 4 & 0 \\
Oil & 34 & 27 & -7 \\
Coal & 28 & 20 & -8 \\
\hline
\end{tabular}

Source: EU Market Outlook, 2019

According to the report by the International Energy Agency (Global Energy Review, 2020), global energy demand declined by $3.8 \%$ in the first quarter of 2020, with most of the impact occurring in March, when Europe, North America and other countries applied restrictive measures. The global demand for coal was hit hardest, declining by almost $8 \%$ compared to the first quarter of 2019 , oil demand declining by almost $5 \%$, gas demand declining by about $2 \%$. At the same time, there was a drop in demand for electricity by $20 \%$, primarily for that which was produced from traditional energy sources (oil, gas, coal, nuclear energy). On the other hand, the positive dynamics of growth in demand for electricity from renewable sources, as well as directly to renewable energy sources (solar energy, wind energy, hydropower, geothermal energy), as well as bioenergy (biofuels and waste energy production) is being monitored. In the context of statistical data (Data and statistics, 2021), in 2018, there was a trend towards an increase in electricity production from renewable energy sources, biofuels and waste. 
In total, in terms of data (Table 2-3) during 2013-2019 in Ukraine, we were tracking the positive dynamics of electricity production and consumption from renewable sources (wind, solar, hydroelectric power plants) biofuels and waste. In this context, we note the importance of deepening activities to implement international standards to produce green energy, diversification of renewable energy sources. Taking into consideration the favorable territorial and climatic features of Ukraine for the agriculture development, it is necessary to adapt international standards for the biofuel production (Halysh et al., 2021). Such dynamics testifies the strengthening of both environmental safety and energy efficiency policy in Ukraine.

Table 2. Stocks of renewable energy sources and traditional energy sources in Ukraine

\begin{tabular}{|c|c|c|c|c|c|c|c|c|}
\hline & Units & 2013 & 2014 & 2015 & 2016 & 2017 & 2018 & 2019 \\
\hline Energy production & thousands & 85914 & 76928 & 61614 & 66323 & 58863 & 60883 & 60095 \\
\hline Energy imports & thousands & 39722 & 34437 & 31575 & 29152 & 35145 & 33847 & 34768 \\
\hline Energy export & thousands & 8213 & 6967 & 1447 & 1427 & 1944 & 1464 & 1830 \\
\hline Coal and peat & thousands & 41427 & 35576 & 27344 & 32450 & 25757 & 28055 & 25718 \\
\hline$\%$ to the total & $\%$ & $35,7 \%$ & $33,7 \%$ & $30,4 \%$ & $34,4 \%$ & $28,8 \%$ & $30,0 \%$ & $28,9 \%$ \\
\hline Raw oil & thousands & 3978 & 3043 & 2851 & 2806 & 3351 & 3635 & 3786 \\
\hline$\%$ to the total & $\%$ & $3,4 \%$ & $2,9 \%$ & $3,2 \%$ & $3,0 \%$ & $3,7 \%$ & $3,9 \%$ & $4,3 \%$ \\
\hline Petroleum products & thousands & 5928 & 7645 & 7700 & 8387 & 9345 & 9690 & 9747 \\
\hline$\%$ to the total & $\%$ & $5,1 \%$ & $7,2 \%$ & $8,5 \%$ & $8,9 \%$ & $10,4 \%$ & $10,4 \%$ & $10,9 \%$ \\
\hline Natural gas & thousands & 39444 & 33412 & 26055 & 25603 & 24554 & 25653 & 23383 \\
\hline$\%$ to the total & $\%$ & $34,0 \%$ & $31,6 \%$ & $28,9 \%$ & $27,1 \%$ & $27,4 \%$ & $27,4 \%$ & $26,3 \%$ \\
\hline Nuclear energy & thousands & 21848 & 23191 & 22985 & 21244 & 22449 & 22145 & 21771 \\
\hline$\%$ to the total & $\%$ & $18,8 \%$ & $21,9 \%$ & $25,5 \%$ & $22,5 \%$ & $25,1 \%$ & $23,7 \%$ & $24,4 \%$ \\
\hline Hydropower & thousands & 1187 & 729 & 464 & 660 & 769 & 897 & 560 \\
\hline$\%$ to the total & $\%$ & $1,0 \%$ & $0,7 \%$ & $0,5 \%$ & $0,7 \%$ & $0,9 \%$ & $1,0 \%$ & $0,6 \%$ \\
\hline Wind and solar energy & thousands & 104 & 134 & 134 & 124 & 149 & 197 & 426 \\
\hline$\%$ to the total & $\%$ & $0,1 \%$ & $0,1 \%$ & $0,1 \%$ & $0,1 \%$ & $0,2 \%$ & $0,2 \%$ & $0,5 \%$ \\
\hline Biofuels and waste & thousands & 1875 & 1934 & 2102 & 2832 & 2989 & 3208 & 3362 \\
\hline$\%$ to the total & $\%$ & $1,6 \%$ & $1,8 \%$ & $2,3 \%$ & $3,0 \%$ & $3,3 \%$ & $3,4 \%$ & $3,8 \%$ \\
\hline Electricity & thousands & -851 & -725 & -116 & -323 & -445 & -522 & -348 \\
\hline$\%$ to the total & $\%$ & $-0,7 \%$ & $-0,7 \%$ & $-0,1 \%$ & $-0,3 \%$ & $-0,5 \%$ & $-0,6 \%$ & $-0,4 \%$ \\
\hline Heat energy & thousands & 1000 & 745 & 571 & 599 & 546 & 534 & 667 \\
\hline$\%$ to the total & $\%$ & $0,9 \%$ & $0,7 \%$ & $0,6 \%$ & $0,6 \%$ & $0,6 \%$ & $0,6 \%$ & $0,7 \%$ \\
\hline
\end{tabular}

Source: Ukrstat, 2020

Considering the paper (Zaverbnyi, 2013) the development of renewable energy will reduce the level of import dependence of our state and reduce the cost of energy production within the state. In addition, we believe that such a reorientation in energy consumption will contribute to enhancing environmental safety.

It should be noted the positive trend of growth in demand for electric vehicles and the expansion of the charging stations geography. In addition, we believe that in order to approve the green energy positioning as an innovative product in the energy market, it is valuable to implement educational campaigns to popularize electric vehicles, to study the environmental behavior of transport users. In this context, it is important to introduce a communication model of participants in the energy services market in the context of urban infrastructure cyclical management (Brych et al., 2020). The expansion of economic activity areas on the use of energy from renewable sources indicates the formation of demand for energy efficiency and energy saving services, as well as the development of partnerships based on sustainable development goals. 
According to the results of the all-Ukrainian sociological survey (Akermann et al., 2019), $90 \%$ of respondents claim that it is customary to use energy and resources in their households. Among the energy efficient measures, the most common are the following ones: installation of meters for various types and modes of service provision ( $84 \%$ ); replacement of windows (76.5\%); reduction in gas consumption (among those who use gas at home $-72.5 \%$ ); decrease in water consumption (66\%). About half of the respondents noted the replacement of lighting on the floors in multi-storey buildings (among those who live in multistorey buildings $-47 \%$ ), the installation of non-gas boilers ( $46 \%)$, the installation of autonomous heating $(43 \%)$. About a third of respondents noted such practices as installing heat meters in a multi-storey building $(38 \%)$, replacing windows in a multi-storey building $(35 \%)$, exterior insulation of a separate apartment or private house $(30.5 \%)$.

Table 3. Energy consumption from renewable energy sources in Ukraine

\begin{tabular}{|c|c|c|c|c|c|c|c|c|}
\hline & Units & 2013 & 2014 & 2015 & 2016 & 2017 & 2018 & 2019 \\
\hline $\begin{array}{l}\text { Total primary } \\
\text { energy supply }\end{array}$ & thousands & 115940 & 105683 & 90090 & 94383 & 89462 & 93492 & 89072 \\
\hline $\begin{array}{l}\text { Total energy } \\
\text { supply from } \\
\text { renewable } \\
\text { sources }\end{array}$ & thousands & 3166 & 2797 & 2700 & 3616 & 3907 & 4302 & 4348 \\
\hline $\begin{array}{l}\text { Share of energy } \\
\text { supplies from } \\
\text { renewable } \\
\text { sources }\end{array}$ & $\%$ & $2,7 \%$ & $2,6 \%$ & $3,0 \%$ & $3,8 \%$ & $4,4 \%$ & $4,6 \%$ & $4,9 \%$ \\
\hline
\end{tabular}

Source: Ukrstat, 2020

On the other hand, respondents note a low level of information and communication companies about the possibilities of using green energy and the introduction of energy-saving technologies. Most of the respondents have heard the term "energy efficiency" in advertising. These are mainly commercial advertisements on television about specific energy-efficient equipment such as energy-saving windows, heaters, water heaters, insulation schemes of a dwelling. Several respondents saw commercial advertisements about energy efficient equipment on YouTube (Akermann et al., 2019).

In Ukraine, within the framework of international grant programs (USAID, GIZ, UNDP, etc.), such state programs to stimulate energy efficiency and energy saving are being implemented as compensation for the population of $20 \%$ of the cost of replacing a gas boiler with a non-gas boiler; "Warm loans", "savings house", "warm house", compensation of $35 \%$ for private households and $40 \%-70 \%$ for joint owners of apartment buildings from the amount of loans for the implementation of energy efficiency measures; $c 0-$ financing of energy efficiency measures by the city council (Akermann et al., 2019). The wide range of energy services implementation, the development of the energy service market, and the green energy market indicate the need to consider the issue of energy market segmentation as a tool for determining the positioning of green energy as an innovative product.

In the scientific literature (Lotysh, 2017; Slokva, 2017), the concept of market segmentation is interpreted as a way of dividing the market into homogeneous groups according to the relevant characteristics (consumers, suppliers, assortment of goods or services, competitors, etc.); analysis of the assortment of all manufacturers on the market, build a map of competitive groups and define the boundaries of price segments. In addition, the most common and practical approach to market segmentation is customer separation (geographic, behavioral, demographic, psychographic). In turn, it is distinguished horizontal (markets are divided by goods, geographic location and consumer groups) and 
vertical (defining and selection of consumer groups at various levels of the target industry; identifies the features of the relationship "supplier - consumer" and product modification by the degree of transition from one level to another) market segmentation. Accordantly, the features of the green energy services' marketing management are the segmentation of the energy market by following factors:

- competitor segment (direct, indirect, strong, weak), consumer types segment (households, industrial enterprises, service companies, government agencies, non-profit organizations),

- energy source segment (suppliers of natural energy sources (gas, oil, coal), suppliers of renewable energy sources (solar energy, wind energy, hydropower), suppliers of bio-raw materials (biofuels), suppliers of waste),

- territorial segment (global, cross-border, national, local),

- product segment (conventional energy (gas, electricity, oil, nuclear energy, heat), alternative energy I green" energy (solar energy, wind energy, hydropower, biofuels (solid (pellets), liquid, biogas), etc.), energy service),

- human potential segment (age, gender, life expectancy, fertility, income level, health status, education, quality of life).

Such segmentation allows you to highlight the directions of the energy market development based on the use and consumption of energy from natural non-renewable sources, the production and consumption of alternative energy (green energy), as well as energy services.

In this context, it should be noted that the active process of reforming the energy market of Ukraine is based on competition and considering international experience. In particular, the electricity market (the Law of Ukraine "On the Electricity Market"), the gas market (the Law of Ukraine "On the Gas Market") are already functioning, which provide the operation of energy distribution systems, diversification of energy supply and the possibility of consumers' independent choice of a gas or electricity supplier. In addition, since 2003, the Law of Ukraine "On Alternative Energy Sources" (On Alternative Energy Sources, 2020) has been in force, which spelled out state administration and regulation, international cooperation in the field of alternative energy sources, the use peculiarities of alternative energy sources (renewable energy sources, which include energy solar, wind, geothermal, hydrothermal, aerothermal, wave and tidal energy, hydropower, biomass energy, landfill gas, sewage treatment plant gas, biogas and secondary energy resources, which include blast furnace and coke oven gases, gas methane degassing of coal deposits, transformation of waste energy potential of technological processes). In addition, in July 2020, the Verkhovna Rada of Ukraine adopted the Law of Ukraine "On Amendments to Certain Laws of Ukraine Concerning Improving the Conditions for Supporting the Production of Electricity from Alternative Energy Sources" (On Amendments to Certain Laws of Ukraine, 2020), in particular by supplementing the Law of Ukraine "On Alternative Energy Sources" with provisions on the regulation of the green tariff.

The existing potential of biomass allows to increase the production of such main types of biofuels in Ukraine as solid biofuels, rare types of motor fuels (biodiesel and bioethanol), biogas from agricultural waste and other organic waste, biomass for heat production and further industrial processing into solid fuel (Halchynska, Larina, 2018). In addition, the base market for the solar energy is the market for practical use (solar energy). For enterprises producing or supplying products for the electricity production from solar energy, the potential is the photovoltaic market (Borysiak, 2021; Pryimak et al., 2020; Brych et al., 2019).

In addition, it is active the process of forming a mechanism for the functioning of the heat power market based on energy efficiency as a result of the transition to the consumption of green energy. In particular, it is important to take into account the following components in the construction and substantiation of a concept model of reforming the heat market in the housing and communal services of Ukraine:

- development of a transparent mechanism for connecting independent manufacturers to heating networks;

- lifting the ban on the privatization of heat generation facilities; 
- establishment of separate tariffs and financial accounting by type of activity;

- formation of a competitive environment in the housing and communal services market;

- use of alternative energy sources;

- a strategy development for the energy service market.

In the context of approving the principles of sustainable development of society, the development of a model for market reform should be based on energy-efficient and energy-saving approaches. The implementation of these approaches, in the conditions of the functioning of business entities of natural monopolies, provides the application of a competitive environment principle.

Such patterns of energy market development in the direction of increasing energy saving and energy efficiency because of the positioning approval of green energy as an innovative product in the energy market is the basis for the expansion of the activities of energy service companies and the development of the energy service market in Ukraine. In accordance with the Law of Ukraine "On the introduction of new investment opportunities, ensuring the rights and legitimate interests of business entities for largescale energy modernization" (On the introduction of new investment opportunities, 2019), energy service is interpreted as a complex of technical and organizational energy saving (energy efficient) and other measures aimed at reducing the customer's energy consumption and / or expenses for payment of fuel and energy resources and / or housing and communal services in comparison with consumption (expenses) in the absence of such measures.

Conclusions. Climate policy in the energy market directs to the limiting natural energy sources. For determining of the level of climate neutral principles' implementation, the improvement of the energy market mechanism is needed. The creation of a competitive environment in such a market is accompanied by the strengthening of the diversification policy of green energy services.

Considering this, energy services companies estimate the efficiency of the green energy services' marketing management based on segmentation. The use of the interval models described by the discrete difference equations to defining the green energy estimating as an innovative product in the energy market. Taking this into account, a promising direction for further research is the development of a methodological approach to assessing the management model of promoting green energy services in the context of development smart energy grids.

Author Contributions: conceptualization, B. V.; methodology, D. O., Z. T.; software, B. O.; validation, V. O.; formal analysis, B. O., V. O.; investigation, Z. T., B. V.; resources, D. O.; data curation, V. O.; writing - original draft preparation, Z. T., D. O., B. O.; writing - review and editing, B. V., V. O.; supervision, D. O.

Funding: This research received no external funding.

\section{References}

Akermann, A., Koval-Honchar, M., Hrushetskyi, A., \& Lypova, P. (2019). Results of the all-Ukrainian sociological survey "Opinions and Views of the Population of Ukraine on Energy Efficiency and Energy Saving". [Link]

Borysiak, O.V. (2021). Peculiarities of digital transformation in the promoting climate policy of alternative energy enterprises. SWorld Journal, 4(8), 83-89. [Google Scholar]

Brych, V., Dyvak, M., Porplytsya, N., Halysh, N., Tulai, O. \& Shpak, Y. (2019). Modeling of Dynamics of the Company's Share in the Solid Fuel Market. 9th International Conference on Advanced Computer Information Technologies (ACIT). Ceske Budejovice, Czech Republic, 354-357. [CrossRef]

Brych, V., Manzhula, V., Borysiak, O., Liakhovych, G., Halysh, N., \& Tolubyak, V. (2020). Communication Model of Energy Service Market Participants in the Context of Cyclic Management City Infrastructure, Proceedings of the $10^{\text {th }}$ International Conference on Advanced Computer Information Technologies (AC/T'2020). Deggendorf, Germany, 678-681. [CrossRef].

Brych, V., Manzhula, V., Halysh, N, Zhekalo, G, Liakhovych, G., \& Vakun, O. (2020). Strategy of Effective Pricing Policy of Biofuel Enterprises. 10th International Conference on Advanced Computer Information Technologies. Deggendorf, Germany, 674677. [CrossRef]

Brych, V., Manzhula, V., Halysh, N., Holubchak, O., Korol, S. \& Stetsko, M. (2019). Management of enterprise's assortment policy by production of solid biofuels. 9th International Conference on Advanced Computer Information Technologies (ACIT). Ceske Budejovice, Czech Republic, 370-373. [CrossRef]. 
Brych, V., Mykytyuk, P., Halysh, N., Borysiak, O., Zhekalo, G., \& Sokol, M. (2021). Management Model of Energy Enterprises Innovative Development Within Physiological Working Conditions. Propósitos y Representaciones, 9(3). [CrossRef]

Data and statistics (2020). International Energy Agency. [Link]

Dontu, A.I., Gaiginschi, L., \& Barsanescu, P.D. (2019). Reducing the urban pollution by integrating weigh-in-motion sensors into intelligent transportation systems: State of the art and future trends. ModTech 2019: 7th International Conference on Modern Technologies in Industrial Engineering (19-22 June, 2019, Romania), 591(1). [Link]

Energy of Ukraine (2020). Infographic guide. [Link]

EU Adaptation Strategy (2021). [Link]

EU Market Outlook for Solar Power 2019-2023 (2019). [Link]

Global Energy Review (2020). The impacts of the Covid-19 crisis on global energy demand and $\mathrm{CO}_{2}$ emissions. International Energy Agency. [Link]

Halchynska, Y.M., \& Larina, Y.S. (2018). Bioenergy market segmentation. Efektyvna ekonomika. [Link]

Halysh, N., Borysiak, O., Brych, V., Korol, V., Vakun, O., \& Zaburanna, L. (2021). Technical and Economic Analysis of Implementation of Standards for Solid Fuels. Lecture Notes in Networks and Systems, 194, 931-942. [CrossRef]

Information notes on the main indicators of development of industries of the fuel and energy complex of Ukraine (2019). [Link] Liakhovych, G., Kupchak, V., Borysiak, O., Huhul, O., Halysh, N., Brych, V., \& Sokol, M. (2021). Innovative human capital management of energy enterprises and the role of shaping the environmental behavior of consumers of green energy based on the work of smart grids. Propósitos y Representaciones, 9(3). [CrossRef]

Lindroos, T.J., Maaki, E., Koponen, K., Hannula, I., Kiviluoma, J., \& Raitila, J. (2021). Replacing fossil fuels with bioenergy in district heating - comparison of technology options. Energy, 231. [CrossRef]

Maaki, E., Kannari, L., Hannula, I., \& Shemeikka, J. (2021). Decarbonisation of a district heating system with a combination of solar heat and bioenergy: a techno-economic case study in the Northern European context. Renewable Energy, 175, 1174-1199. [CrossRef]

Mazzai, A. (2021). Science Feeds Policy: The New European Strategy. [Link]

On Alternative Energy Sources: Law of Ukraine (2020). [Link]

On Amendments to Certain Laws of Ukraine Concerning Improving the Conditions for Supporting the Production of Electric Power from Alternative Energy Sources: Law of Ukraine (2020). [Link]

On the introduction of new investment opportunities, ensuring the rights and legitimate interests of business entities for largescale energy modernization: Law of Ukraine (2020). [Link]

Pryimak, V., Melnyk, B., Holubnyk, O., Kostyshyna, T., \& Brych, V. (2020). A Fuzzy Assessment of the Development of the National Labor Market of Ukraine. 10th International Conference on Advanced Computer Information Technologies (ACIT). Deggendorf, Germany, 682-686. [CrossRef]

Shengin, T., Wang, X., \& Chuanwen, J. (2019). Privacy-preserving energy scheduling for ESCOs based on energy blockchain network. Energies, 12(8), 1530. [CrossRef]

Slokva, M.H. (2017). Segmentation of foreign markets: theoretical and methodological aspects. Ekonomika i orhanizatsiia upravlinnia, 4, 129-142. [Link]

The European Green Deal (2021). [Link]

The new EU Strategy on Adaptation to Climate Change (2021). The European Commission. [Link]

Ukrstat (2019). Total primary energy supplies for 2007-2019. Renewable energy consumption for 2007-2019. [Link]

Urge-Vorsatz, D., Koppel, S., Liang, Ch., Kiss, B., Goopalan, N.G., \& Celikyilmaz, G. (2007). An Assessment of on Energy Service Companies (ESCOs) Worldwide. Central European University. [Link]

Van Der Kam, M., Peters, A., Van Sark, W., \& Alkemade, F. (2019). Agent-based modelling of charging behavior of electric vehicle drivers. Journal of Artificial Societies and Social Simulation, 22(4). [CrossRef]

Zatonatska, T., \& Dluhopolskyi, O. (2019). Modelling the efficiency of the cloud computing implementation at enterprises. Marketing and Management of Innovations, 3, 45-59. [CrossRef]

Zatonatska, T., Dluhopolskyi, O., Chyrak, I., \& Kotys, N. (2019). The Internet and e-commerce diffusion in European countries (modeling at the example of Austria, Poland, and Ukraine). Innovative Marketing, 15(1), 66-75. [CrossRef]

Zaverbny, A. (2013). Peculiarities of development and reforming markets of electric energy as one of the key energy products in the European Union. ECONTECHMOD: An International Quarterly Journal on Economics of Technology and Modelling Processes, 2. [Google Scholar]

Василь Брич, д.е.н., професор, Західноукраїнський національний університет, Україна

Тетяна Затонацька, д.е.н., професор, Київський національний університет імені Тараса Шевченка, Україна

Олександр Длугопольський, д.е.н., професор, Західноукраїнський національний університет, Україна

Олена Борисяк, к.е.н., Західноукраїнський національний університет, Україна

Оксана Вакун, к.е.н., доцент, Західноукраїнський національний університет, Україна

Оцінювання ефективності управління маркетинговими послугами зеленої енергетики на основі сегментації

Енергетична безпека зазнає суттєвих ризиків як на етапах виробництва, розподілу, так і на етапах постачання й споживання енергії. Сезонне зменшення або збільшення споживчого попиту на енергоресурси через зміни клімату негативно 
V., Brych, T., Zatonatska, O., Dluhopolskyi, O., Borysiak, O., Vakun. Estimating the Efficiency of the Green Energy Services' Marketing Management Based on Segmentation

впливає на збалансування енергетичної системи. Стаття присвячена оцінці факторів маркетингового управління послугами «зеленої енергетики» та розробці моделі оцінки зеленої енергії як інноваційного продукту на основі сегментації ринку енергії. Сегментація енергетичного ринку дозволяє виокремити його базові складові як на основі використання та споживання енергії з природних невідновлюваних джерел, так і виробництва та споживання альтернативної енергії (зелена енергія), а також енергетичних послуг різного рівня. Проаналізовано стан інноваційного розвитку зеленої енергетики як продукту, екологічно чистих енергетичних послуг та інтелектуальної енергомережі на основі використання енергії з природних відновлюваних джерел. Відзначена позитивна тенденція зростання попиту на електромобілі та розширення географії зарядних станцій. Для подальшого позиціонування зеленої енергії як інноваційного продукту на енергетичному ринку доцільним $є$ проведення освітніх кампаній з популяризації електромобілів, вивчення екологічної поведінки користувачів транспорту тощо. Активний процес реформування енергетичного ринку України ґрунтується на конкуренції та враховує міжнародний досвід реформування. Зокрема, вже функціонують ринок електроенергії, ринок газу, які забезпечують роботу систем розподілу енергії, диверсифікацію енергоносіїв постачання та можливість незалежного вибору споживачами постачальника газу чи електроенергії. Використано інтегрований сегментний підхід до моделювання оцінки екологічної енергії як інноваційного продукту на енергетичному ринку, а також інтервальні моделі, описані дискретними рівняннями. Беручи це до уваги вищенаведене, перспективним напрямком для подальших досліджень є розробка методологічного підходу до оцінки моделі управління просуванням послуг із зеленої енергетики в контексті розвитку розумних енергомереж.

Ключові слова: сегменти ринку, сталий розвиток, зміна клімату, альтернативна енергетика, кліматична політика, відновлювані джерела енергії, безпека енергії та навколишнього середовища, управління енергією, розумні мережі. 